\title{
RISK FACTORS OF GONORRHOEA AMONG FEMALE INDIRECT SEX WORKERS
}

\author{
Anita Nugrahaeni' ${ }^{1}$, Muchlis AU Sofro'), Zahroh Shaluhiyah'3) \\ Antono Suryosaputro3), Bagoes Widjanarko3) \\ 1) Masters Program in Epidemiology, Diponegoro University \\ ${ }^{2)}$ Department of Internal Medicine, Faculty of Medicine, \\ Diponegoro University \\ 3)Department of Health Promotion, Faculty of Public Health, \\ Diponegoro University
}

\begin{abstract}
Background: Gonorrhoea is one of sexually transmitted infections (STI) with high incidence, besides chlamydia, syphilis, and trichomoniasis. STIs are spread predominantly by sexual context including vaginal, anal, and oral. STIs have a profound impact on sexual and reproductive health worldwide. STIs can increase the risk of HIV acquisition three fold or more. This study aimed to determine the risk factors of gonorrhoea among female indirect sex workers.
\end{abstract}

Subjects and Method: This was a case control study carried out in Wonosobo district, Central Java, from April to May 2017. A sample of 84 female indirect sex workers were selected for this study consisting of 42 cases of gonorrhea and 42 control. The dependent variable was gonorrhoea. The independent variables were sex combination and condom use. Data on gonorrhoea was collected from STI clinic. The other data were collected by questionnaire. The data were analyzed using logistic regression.

Results: The risk of gonorrhoea among female indirect sex workers increased with sex combination practice $(\mathrm{OR}=3.17 ; \mathrm{p}=0.027 ; 95 \% \mathrm{CI}=1.14$ to 8.82) and absence of condom use $(\mathrm{OR}=8.04 ; 95 \% \mathrm{CI}=2.30$ to 28.12 ; $\mathrm{p}=0.001)$.

Conclusion: The risk of gonorrhoea among female indirect sex workers increases with sex combination practice and absence of condom use.

Keywords : gonorrhoea, sex combination, condom use, female, indirect sex workers

Correspondence: Anita Nugrahaeni. Masters Program in Epidemiology, Diponegoro University, Jl. Imam Bardjo SH No. 5, Semarang, Central Java. Email: nitaozora@gmail.com. Mobile: +6281335980666. 